\title{
Synthesis, Crystal Structures, and DNA Binding Properties of Zinc(II) Complexes with 3-Pyridine Aldoxime
}

\author{
Konstantis F. Konidaris, ${ }^{1}$ Rigini Papi, ${ }^{2}$ Eugenia Katsoulakou, ${ }^{1}$ Catherine P. Raptopoulou, ${ }^{3}$ \\ Dimitrios A. Kyriakidis, ${ }^{2}$ and Evy Manessi-Zoupa ${ }^{1}$
}

${ }^{1}$ Department of Chemistry, University of Patras, 26504 Patras, Greece
2 Department of Chemistry, Aristotle University of Thessaloniki, 54124 Thessaloniki, Greece
${ }^{3}$ Institute of Materials Science, NCSR "Demokritos", 15310 Aghia Paraskevi Attikis, Greece

Correspondence should be addressed to Evy Manessi-Zoupa, emane@upatras.gr

Received 25 August 2010; Accepted 14 September 2010

Academic Editor: Spyros Perlepes

Copyright (C) 2010 Konstantis F. Konidaris et al. This is an open access article distributed under the Creative Commons Attribution License, which permits unrestricted use, distribution, and reproduction in any medium, provided the original work is properly cited.

The employment of 3-pyridine aldoxime, (3-py)CHNOH, in $\mathrm{Zn}^{\mathrm{II}}$ chemistry has afforded two novel compounds: [ $\mathrm{Zn}(\mathrm{acac})_{2}\{(3-$ py) $\mathrm{CHNOH}\}] \cdot \mathrm{H}_{2} \mathrm{O}\left(\mathbf{1} \cdot \mathrm{H}_{2} \mathrm{O}\right)$ [where acac ${ }^{-}$is the pentane-2,4-dionato(-1) ion] and $\left[\mathrm{Zn}_{2}\left(\mathrm{O}_{2} \mathrm{CMe}\right)_{4}\{(3-\mathrm{py}) \mathrm{CHNOH}\}_{2}\right](\mathbf{2})$. Complex $1 \cdot \mathrm{H}_{2} \mathrm{O}$ crystallizes in the monoclinic space group $P 2_{1} / n$. The $\mathrm{Zn}^{\mathrm{II}}$ ion is five-coordinated, surrounded by four oxygen atoms of two $\mathrm{acac}^{-}$moieties and by the pyridyl nitrogen atom of the (3-py) CHNOH ligand. Molecules of 1 interact with the water lattice molecules forming a 2D hydrogen-bonding network. Complex 2 crystallizes in the triclinic $P-1$ space group and displays a dinuclear paddle-wheel structure. Each $\mathrm{Zn}^{\mathrm{II}}$ exhibits a perfect square pyramidal geometry, with four carboxylate oxygen atoms at the basal plane and the pyridyl nitrogen of one monodentate (3-py)CHNOH ligand at the apex. DNA mobility shift assays were performed for the determination of the in vitro effect of both complexes on the integrity and the electrophoretic mobility of pDNA.

\section{Introduction}

During the last decades, there has been considerable interest in the interaction of small molecules with DNA $[1,2]$. DNA is generally the primary intracellular target of anticancer drugs, so such interactions can cause damage in cancer cells, block their division and consequently result in cell death [3]. Small synthetic binders can interact with DNA through the following three noncovalent modes: intercalation, groove binding, and external static electronic effects [4]. Transition metal complexes are a particularly interesting class of DNAbinders because of their cationic character, well-defined three-dimensional structure, aptitude to perform hydrolysis and redox reactions, as well as extensively developed substitution chemistry that allows easy modulations of their binding and reactive properties [5].

Among the various metal ions studied with nucleic acids and nucleobases, $\mathrm{Zn}^{\mathrm{II}}$ has occupied a special position [6], mainly due to the following reasons [7]: $\mathrm{Zn}^{\mathrm{II}}$ is a strong Lewis acid and exchanges ligands very rapidly; is of low toxicity; it has no redox chemistry, catalyzing only hydrolytic cleavage of DNA. For all the above mentioned reasons, the binding of $\mathrm{Zn}$ II complexes with DNA has attracted much attention $[8,9]$. It has been reported that the binding properties of the complexes depend on several factors, such as the coordination geometry, the type of the donor-atoms and the planarity of ligands [10].

The ligand used in this work (Scheme 1) belongs to the family of pyridyl oximes. The coordination chemistry of these compounds has been extensively explored over the last two decades, mainly with paramagnetic $3 \mathrm{~d}$ metal ions towards new molecular materials with interesting magnetic properties [11]. As a consequence, the diamagnetic character of the $\mathrm{Zn}$ " ion has led to a "gap" in the literature, concerning the area of the coordination chemistry of oximes. Recently, we have tried to fill this gap by the use of simple pyridyl oximes (the term "simple" means here ligands with only one pyridyl and one oxime group as donors) in $\mathrm{Zn}^{\mathrm{II}}$ coordination 


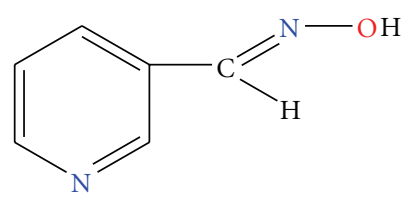

(3-py) $\mathrm{CHNOH}$

Scheme 1: Structural formula and abbreviation of the ligand employed in this work.

chemistry. We reported the largest up to date $\mathrm{Zn}$ (II)/oxime cluster [12], as well as the first complexes of $\mathrm{Zn}^{\mathrm{II}}$ with 3- and 4-pyridine aldoxime [13].

In this study, our efforts were initiated by the synthesis and characterization of new $\mathrm{Zn}^{\mathrm{II}} / 3$-pyridine aldoxime complexes, while our next objective was to investigate the interaction of these compounds with plasmid DNA. The structural formula of the free ligand is illustrated in Scheme 1.

\section{Experiments}

2.1. Starting Materials and Physical Measurements. All manipulations were performed under aerobic conditions using reagents and solvents as received. Zinc acetylacetonate, zinc acetate, and 3-pyridinealdoxime were purchased from Aldrich Co. Elemental analyses $(\mathrm{C}, \mathrm{H}, \mathrm{N})$ were performed by the University of Ioannina (Greece) Microanalytical Laboratory using an EA 1108 Carlo Erba analyzer. IR spectra (4000-450 $\mathrm{cm}^{-1}$ ) were recorded on a Perkin-Elmer 16 PC FT-IR spectrometer with samples prepared as $\mathrm{KBr}$ pellets.

pDNA isolation was performed from a fully grown culture of Escherichia coli Top10F- harboring the pBluescript plasmid. The Macherey-Nagel plasmid DNA isolation kit was used. All plastics and glassware used in the experiments were autoclaved for $30 \mathrm{~min}$ at $120^{\circ} \mathrm{C}$ and $130 \mathrm{Kpa}$.

\subsection{Compound Preparation}

2.2.1. Preparation of $\left.\left[\mathrm{Zn}(\text { acac })_{2}\{(3-p y) C H N O H)\right\}\right] \cdot \mathrm{H}_{2} \mathrm{O}\left(\mathbf{1} \cdot \mathrm{H}_{2} \mathrm{O}\right)$. $\mathrm{Zn}(\mathrm{acac})_{2} \cdot \mathrm{H}_{2} \mathrm{O} \quad(0.210 \mathrm{~g}, 0.80 \mathrm{mmol})$ was suspended in $\mathrm{MeOH}\left(10 \mathrm{~cm}^{3}\right)$ and then dissolved upon stirring by adding a solution of (3-py)CHNOH $(0.195 \mathrm{~g}, 1.60 \mathrm{mmol})$ in the same solvent $\left(10 \mathrm{~cm}^{3}\right)$. The resulting colourless solution was stirred at ambient temperature for $30 \mathrm{~min}$ and allowed to slowly evaporate at room temperature. Well-formed, X-ray quality colourless crystals of the product appeared within a period of four days. The crystals were collected by vacuum filtration, washed with cold $\mathrm{MeOH}\left(2 \times 2 \mathrm{~cm}^{3}\right)$ and $\mathrm{Et}_{2} \mathrm{O}$ $\left(3 \times 5 \mathrm{~cm}^{3}\right)$, and dried in air. The yield was ca. $65 \%$. Found \%: C, 47.60; H, 5.84; N, 6.73. Calc \% for $\mathrm{C}_{16} \mathrm{H}_{24} \mathrm{~N}_{2} \mathrm{O}_{6} \mathrm{Zn}$ : C, 47.36; H, 5.96; N, 6.90. IR data $\left(\mathrm{KBr}, \mathrm{cm}^{-1}\right): 3468$ (wb), 3196 (wb), 3084 (wb), 2998 (w), 2960 (w), 2914 (w), 2804 (w), 1956 (vw), 1654 (sh), 1586 (s), 1552 (vs), 1400 (s), 1340 (sh), 1316 (sh), 1268 (m), 1190 (m), 1124 (w), 1102 (vw), 1058 (vw), 1020 (w), $986(\mathrm{~m}), 928$ (w), 890 (vw), 818 (vw), $770(\mathrm{w}), 702(\mathrm{w}), 654(\mathrm{w}), 560(\mathrm{w}), 528(\mathrm{vw})$, and $464(\mathrm{vw})$.
2.2.2. Preparation of $\left[\mathrm{Zn}_{2}\left(\mathrm{O}_{2} \mathrm{CMe}\right)_{4}\{(3-p y) C H N O H\}_{2}\right]$ (2). $\mathrm{Zn}\left(\mathrm{O}_{2} \mathrm{CMe}\right)_{2} \cdot 2 \mathrm{H}_{2} \mathrm{O}(0.110 \mathrm{~g}, 0.50 \mathrm{mmol})$ was suspended in $\mathrm{Me}_{2} \mathrm{CO}\left(10 \mathrm{~cm}^{3}\right)$ and then dissolved upon stirring by adding a solution of (3-py)CHNOH $(0.122 \mathrm{~g}, 1.00 \mathrm{mmol})$ in the same solvent $\left(10 \mathrm{~cm}^{3}\right)$. The resulting colourless solution was stirred at ambient temperature for $30 \mathrm{~min}$ and then layered with $\mathrm{n}$-hexane $\left(40 \mathrm{~cm}^{3}\right)$. Slow mixing gave well-formed, $\mathrm{X}$ ray quality crystals of the product. The colourless crystals were collected by filtration, washed with cold $\mathrm{Me}_{2} \mathrm{CO}(2 \times$ $\left.3 \mathrm{~cm}^{3}\right)$ and $\mathrm{Et}_{2} \mathrm{O}\left(2 \times 3 \mathrm{~cm}^{3}\right)$, and dried in air. The yield was ca. 53\%. Found \%: C, 39.10; H, 4.01; N, 9.23. Calc \% for $\mathrm{C}_{20} \mathrm{H}_{24} \mathrm{~N}_{4} \mathrm{O}_{10} \mathrm{Zn}_{2}$ : C, 39.34; $\mathrm{H}, 3.94 ; \mathrm{N}, 9.17$. IR data $(\mathrm{KBr}$, $\left.\mathrm{cm}^{-1}\right)$ : $3454(\mathrm{wb}), 3192(\mathrm{~m}), 3084(\mathrm{~m}), 2996(\mathrm{~m}), 2962(\mathrm{~m})$, 2914 (m), 2808 (w), 1656 (sh), 1586 (vs), 1522 (s), 1400 (vs), 1340 (s), 1316 (s), 1268 (s), 1192 (w), 1124 (w), 1102 (vw), $1058(\mathrm{vw}), 1020(\mathrm{~m}), 986(\mathrm{~s}), 928(\mathrm{~m}), 890(\mathrm{w}), 818(\mathrm{~m}), 770$ (m), $702(\mathrm{~m}), 682(\mathrm{w}) 654(\mathrm{w}), 562(\mathrm{w})$, and $418(\mathrm{vw})$.

2.3. X-Ray Crystal Structure Determination. Crystals of 1. $\mathrm{H}_{2} \mathrm{O}(0.22 \times 0.34 \times 0.45 \mathrm{~mm})$ and $2(0.12 \times 0.14 \times$ $0.24 \mathrm{~mm}$ ) were mounted in capillary. Diffraction measurements for $\mathbf{1} \cdot \mathrm{H}_{2} \mathrm{O}$ were made on a Crystal Logic Dual Goniometer diffractometer using graphite monochromated Mo radiation, and for 2 on a $\mathrm{P} 22_{1}$ Nicolet diffractometer upgraded by Crystal Logic using graphite monochromated $\mathrm{Cu}$ radiation. Unit cell dimensions were determined and refined by using the angular settings of 25 automatically centered reflections in the ranges of $11<2 \theta<23^{\circ}$ (for $1 \cdot \mathrm{H}_{2} \mathrm{O}$ ) and $22<2 \theta<54^{\circ}$ (for 2 ) and they appear in Table 1 . Intensity data were recorded using a $\theta-2 \theta$ scan. Three standard reflections monitored every 97 reflections showed less than 3\% variation and no decay. Lorentz, polarization and psi-scan absorption (only for $\mathbf{1} \cdot \mathrm{H}_{2} \mathrm{O}$ ) corrections were applied using Crystal Logic software. The structures were solved by direct methods using SHELXS-97 [14] and refined by full-matrix least-squares techniques on $\mathrm{F}^{2}$ with SHELXL97 [15]. Further experimental crystallographic details for 1. $\mathrm{H}_{2} \mathrm{O}: 2 \theta_{\max }=50^{\circ}$; reflections collected/unique/used, $3449 / 3284\left[\mathrm{R}_{\text {int }}=0.0179\right] / 3284 ; 269$ parameters refined; $(\Delta / \sigma)_{\max }=0.001 ;(\Delta \rho)_{\max } /(\Delta \rho)_{\min }=0.453 /-0.457 \mathrm{e} / \AA^{3} ;$ $R 1 / \mathrm{w} R 2$ (for all data), $0.0371 / 0.834$. Further experimental crystallographic details for $2: 2 \theta \max =118^{\circ}$; reflections collected/unique/used, 1964/1820 $\left[\mathrm{R}_{\text {int }}=0.0538\right] / 1820 ; 167$ parameters refined; $(\Delta / \sigma)_{\max }=0.000 ;(\Delta \rho)_{\max } /(\Delta \rho)_{\min }=$ $0.559 /-0.553 e / \AA^{3} ; R 1 / \mathrm{w} R 2$ (for all data), 0.0524/0.1205. Hydrogen atoms were either located by difference maps and were refined isotropically or were introduced at calculated positions as riding on bonded atoms. All nonhydrogen atoms were refined anisotropically. CCDC codes 789660 and 789661 contain the supplementary crystallographic data for this paper. This data can be obtained free of charge at http://www.ccdc.cam.ac.uk/conts/retrieving.html [or from the Cambridge Crystallographic Data Centre, 12 Union Road, Cambridge CB2 1EZ, UK; Fax: ++44-1223-336 033; E-mail: deposit@ccdc.cam.ac.uk].

2.4. Effect on pDNA. $0.1 \mu \mathrm{g}$ of pBluescript were incubated at $25^{\circ} \mathrm{C}$ in the presence of various concentrations of the 
TABLE 1: Crystallographic data for complexes $\mathbf{1} \cdot \mathrm{H}_{2} \mathrm{O}$ and 2.

\begin{tabular}{|c|c|c|}
\hline Parameter & $\mathbf{1} \cdot \mathrm{H}_{2} \mathrm{O}$ & 2 \\
\hline Formula & $\mathrm{C}_{16} \mathrm{H}_{22} \mathrm{~N}_{2} \mathrm{O}_{6} \mathrm{Zn}$ & $\mathrm{C}_{20} \mathrm{H}_{24} \mathrm{~N}_{4} \mathrm{O}_{10} \mathrm{Zn}_{2}$ \\
\hline Fw & 403.73 & 611.17 \\
\hline Space group & $P 2_{1} / n$ & $P-1$ \\
\hline$a(\AA)$ & $10.531(4)$ & $7.934(5)$ \\
\hline$b(\AA)$ & $15.779(5)$ & $10.153(6)$ \\
\hline$c(\AA)$ & $11.602(4)$ & $8.392(5)$ \\
\hline$\alpha\left(^{\circ}\right)$ & 90 & $70.05(2)$ \\
\hline$\beta\left(^{\circ}\right)$ & $101.17(1)$ & $87.34(2)$ \\
\hline$\gamma\left({ }^{\circ}\right)$ & 90 & $89.07(3)$ \\
\hline$V\left(\AA^{3}\right)$ & $1891.4(11)$ & $634.8(7)$ \\
\hline $\mathrm{Z}$ & 4 & 1 \\
\hline$T\left({ }^{\circ} \mathrm{C}\right)$ & 25 & 25 \\
\hline Radiation & Mo K $\alpha$ & $\mathrm{Cu} \mathrm{K} \alpha$ \\
\hline$\rho_{\text {calcd }}\left(\mathrm{g} \mathrm{cm}^{-3}\right)$ & 1.418 & 1.599 \\
\hline$\mu\left(\mathrm{mm}^{-1}\right)$ & 1.331 & 2.856 \\
\hline Reflections with $I>2 \sigma(I)$ & 2865 & 1585 \\
\hline$R_{1}^{a}$ & 0.0302 & 0.0438 \\
\hline$w R_{2}^{a}$ & 0.0785 & 0.1125 \\
\hline
\end{tabular}

$a_{w}=1 /\left[\sigma^{2}\left(F_{o}^{2}\right)+(\alpha P)^{2}+b P\right]$ and $\left.P=\left(\max F_{0}^{2}, 0\right)+2 F_{\mathrm{c}}^{2}\right) / 3$

$R_{1}=\Sigma\left(\left|F_{\mathrm{o}}\right|-\left|F_{\mathrm{o}}\right|\right) / \Sigma\left(\left|F_{\mathrm{o}}\right|\right)$ and $w R_{2}=\left\{\Sigma\left[w\left(F_{o^{2}}-F_{c}^{2}\right)^{2}\right] / \Sigma\left[w\left(F_{\mathrm{o}}^{2}\right)^{2}\right]\right\}^{1 / 2}$.

complexes under study. After $1 \mathrm{~h}$ at $25^{\circ} \mathrm{C}$ the reaction was terminated by the addition of loading buffer consisting of $0.25 \%$ bromophenol blue, $0.25 \%$ xylene cyanol FF and 30\% (v/v) glycerol in water. The products resulting from DNAcompound interactions were separated by electrophoresis on agarose gels $(1 \% \mathrm{w} / \mathrm{v})$, which contained $1 \mu \mathrm{g} / \mathrm{ml}$ ethidium bromide (EtBr) in $40 \mathrm{mM}$ Tris-acetate, $\mathrm{pH} 7.5,20 \mathrm{mM}$ sodium acetate, $2 \mathrm{mM} \mathrm{Na} 2 \mathrm{EDTA}$, at $5 \mathrm{~V} / \mathrm{cm}$. Agarose gel electrophoresis was performed in a horizontal gel apparatus (Mini-Sub $^{\mathrm{TM}}$ DNA Cell, BioRad) for about $4 \mathrm{~h}$. The gels were visualized in the presence of UV light. All assays were duplicated.

\section{Results and Discussion}

3.1. Synthetic Comments. Our previous investigation on the reaction between $\mathrm{Zn}\left(\mathrm{O}_{2} \mathrm{CPh}\right)_{2}$ and (3-py) $\mathrm{CHNOH}$ led to a trinuclear benzoate cluster [13]. In a subsequent step, we expanded our research to similar or different types of bidentate ligands, such as $\mathrm{MeCO}_{2}^{-}$and $\mathrm{acac}^{-}$, respectively.

Our initial efforts involved the reaction of $\mathrm{Zn}(\mathrm{acac})_{2} \cdot \mathrm{H}_{2} \mathrm{O}$ with one equivalent of (3-py)CHNOH in $\mathrm{MeOH}$, which afforded colourless parallelepiped crystals of $1 \cdot \mathrm{H}_{2} \mathrm{O}$ upon slow evaporation of the reaction solution. Its formation can be represented by the equation (1)

$$
\begin{gathered}
\mathrm{Zn}(\mathrm{acac})_{2} \cdot \mathrm{H}_{2} \mathrm{O}+(3-\text { py }) \mathrm{CHNOH} \\
\stackrel{\mathrm{MeOH}}{\longrightarrow}\left[\mathrm{Zn}(\text { acac })_{2}\{(3-\text { py }) \mathrm{CHNOH}\}\right] \cdot \mathrm{H}_{2} \mathrm{O} \\
\mathbf{1} \cdot \mathrm{H}_{2} \mathrm{O}
\end{gathered}
$$

Treatment of $\mathrm{Zn}\left(\mathrm{O}_{2} \mathrm{CMe}\right)_{2} \cdot 2 \mathrm{H}_{2} \mathrm{O}$ with two equivalents of (3-py) $\mathrm{CHNOH}$ in $\mathrm{Me}_{2} \mathrm{CO}$ afforded colourless parallelepiped crystals of $\mathbf{2}$ upon layering of the reaction solution with $\mathrm{n}$-hexane. The chemically balanced equation for the synthesis of $\mathbf{2}$ is:

$$
\begin{aligned}
& 2 \mathrm{Zn}\left(\mathrm{O}_{2} \mathrm{CMe}\right)_{2} \cdot 2 \mathrm{H}_{2} \mathrm{O}+2(3-\text { py }) \mathrm{CHNOH} \\
& \stackrel{\mathrm{Me}_{2} \mathrm{CO}}{\longrightarrow}\left[\mathrm{Zn}_{2}\left(\mathrm{O}_{2} \mathrm{CMe}\right)_{4}\{(3-\text { py }) \mathrm{CHNOH}\}_{2}\right]+4 \mathrm{H}_{2} \mathrm{O}
\end{aligned}
$$$$
2
$$

As a next step, we tried to modify the structural identity of $\mathbf{1} \cdot \mathrm{H}_{2} \mathrm{O}$ by using excess of $\mathrm{Zn}(\mathrm{acac})_{2} \cdot \mathrm{H}_{2} \mathrm{O}$. A probable result would be the isolation of a paddle wheel structure with four bidentate bridging $\mathrm{acac}^{-}$ligands and two monodentate (3-py) $\mathrm{CHNOH}$ ligands, that is, a structure analogous to that of compound 2. Unfortunately, our efforts did not yield fruits; all the reactions lead to the isolation of solids corresponding to compound $\mathbf{1} \cdot \mathrm{H}_{2} \mathrm{O}$, emphasizing the reduced (compared to carboxylates) bridging capability of $\mathrm{acac}^{-}$.

3.2. Description of Structures. Aspects of the molecular and crystal structures of complexes $\mathbf{1} \cdot \mathrm{H}_{2} \mathrm{O}$ and $\mathbf{2}$ are shown in Figures 1-4. Selected interatomic distances and angles are listed in Tables 2 and 3, while important hydrogen bonding interactions are presented in Table 4.

Complex $1 \cdot \mathrm{H}_{2} \mathrm{O}$ crystallizes in the monoclinic space group $P 2_{1} / n$. Its crystal structure consists of mononuclear $\left[\mathrm{Zn}(\mathrm{acac})_{2}\{(3\right.$-py) $\mathrm{CHNOH}\}]$ molecules and $\mathrm{H}_{2} \mathrm{O}$ molecules 


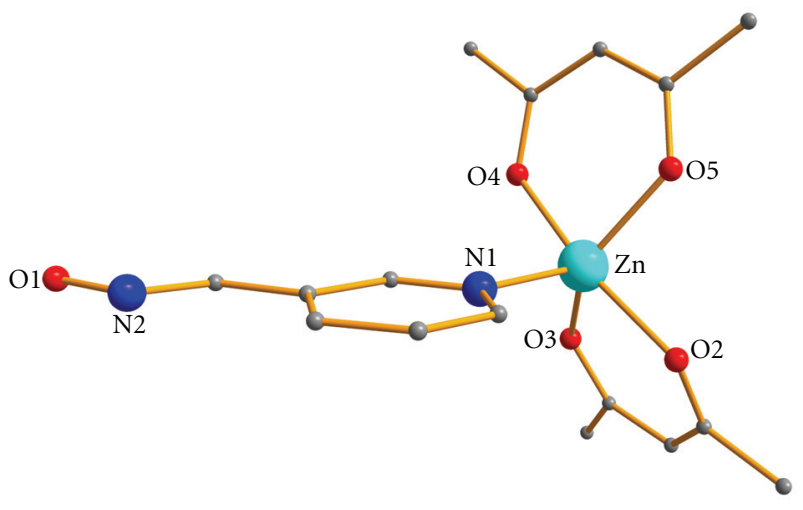

Figure 1: Partially labeled plot of the molecular structure of $\mathbf{1} \cdot \mathrm{H}_{2} \mathrm{O}$. $\mathrm{H}$ atoms and the solvate $\mathrm{H}_{2} \mathrm{O}$ molecule have been omitted for clarity.

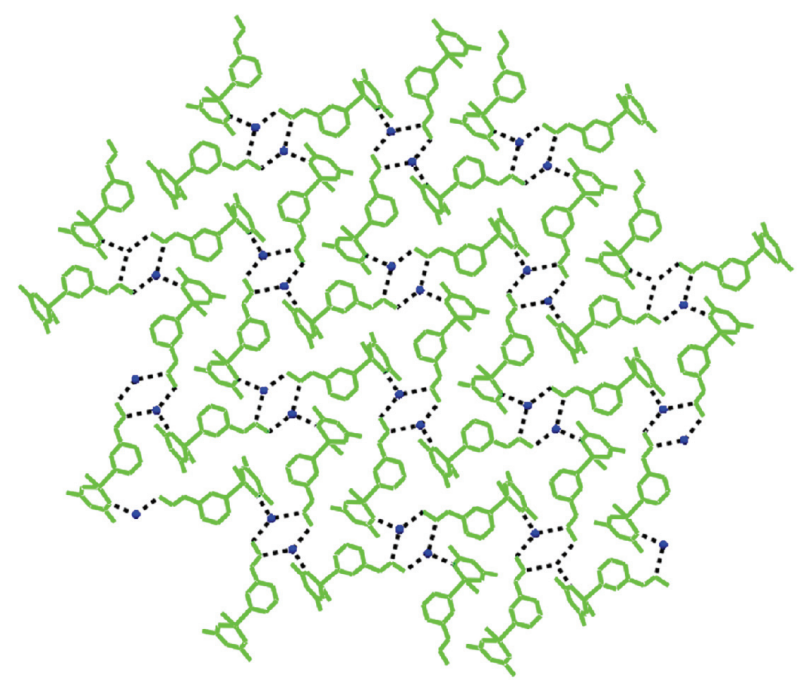

Figure 2: A part of the 2D network in the crystal lattice of $\mathbf{1} \cdot \mathrm{H}_{2} \mathrm{O}$ due to hydrogen bonding interactions (dashed lines). Oxygen atoms of the water lattice molecules are represented by blue spheres.

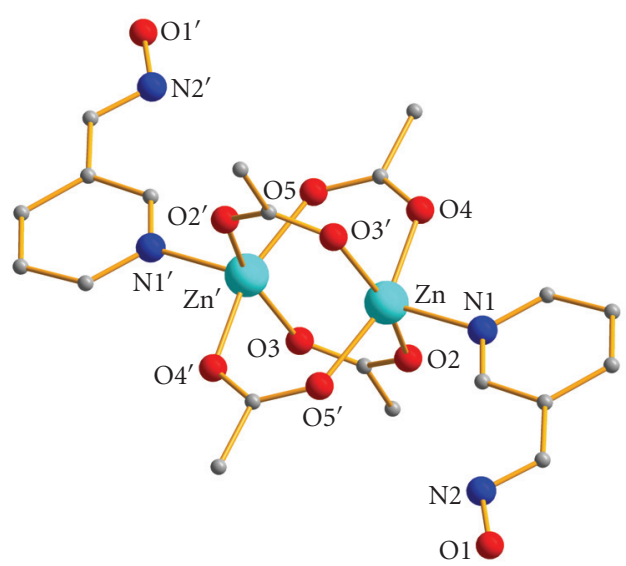

Figure 3: Partially labeled plot of the molecular structure of $2 \cdot \mathrm{H}$ atoms have been omitted for clarity.
Table 2: Selected interatomic distances $(\AA)$ and angles $\left(^{\circ}\right)$ for complex $\mathbf{1} \cdot \mathrm{H}_{2} \mathrm{O}$.

\begin{tabular}{lccc}
\hline $\mathrm{Zn}-\mathrm{O}(2)$ & $2.055(2)$ & $\mathrm{Zn}-\mathrm{O}(3)$ & $1.988(2)$ \\
$\mathrm{Zn}-\mathrm{O}(4)$ & $2.029(2)$ & $\mathrm{Zn}-\mathrm{O}(5)$ & $2.000(2)$ \\
$\mathrm{Zn}-\mathrm{N}(1)$ & $2.073(2)$ & & \\
\hline $\mathrm{O}(3)-\mathrm{Zn}-\mathrm{O}(5)$ & $137.1(9)$ & $\mathrm{O}(4)-\mathrm{Zn}-\mathrm{O}(2)$ & $169.1(8)$ \\
$\mathrm{O}(3)-\mathrm{Zn}-\mathrm{O}(4)$ & $88.5(8)$ & $\mathrm{O}(3)-\mathrm{Zn}-\mathrm{N}(1)$ & $113.1(8)$ \\
$\mathrm{O}(5)-\mathrm{Zn}-\mathrm{O}(4)$ & $89.6(7)$ & $\mathrm{O}(5)-\mathrm{Zn}-\mathrm{N}(1)$ & $109.7(8)$ \\
$\mathrm{O}(3)-\mathrm{Zn}-\mathrm{O}(2)$ & $89.00(8)$ & $\mathrm{O}(4)-\mathrm{Zn}-\mathrm{N}(1)$ & $94.5(8)$ \\
$\mathrm{O}(5)-\mathrm{Zn}-\mathrm{O}(2)$ & $85.1(7)$ & $\mathrm{O}(2)-\mathrm{Zn}-\mathrm{N}(1)$ & $96.3(7)$ \\
\hline
\end{tabular}

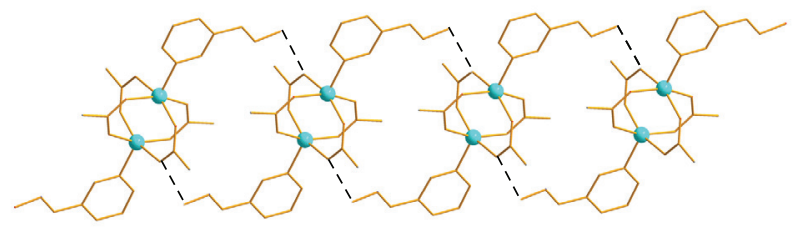

FIGURE 4: A small portion of the ladder-like 1D architectures of 2 due to $\mathrm{H}$-bonding interactions (black dashed lines). The $\mathrm{H}$ atoms have been omitted for clarity.

being present in the lattice. The metal center is fivecoordinated surrounded by two acetylacetonate $\left(\mathrm{acac}^{-}\right)$and one (3-py) CHNOH ligand. Each of the $\mathrm{acac}^{-}$moiety acts in a bidentate chelating way, while the (3-py)CHNOH behaves as a monodentate ligand via the nitrogen atom of the pyridine ring. The coordination geometry of the $\mathrm{Zn}^{\mathrm{II}}$ ion is heavily distorted and thus it can be either described as distorted square pyramidal or as distorted trigonal bipyramidal. Analysis of the shape-determining angles using the approach of Reedijk and coworkers [16] yields a trigonality index, $\tau$, value of 0.53 ( $\tau=0$ and 1 for perfect sp and tbp geometries, respectively). By adopting the square pyramidal geometry, the basal plane is occupied by four acetylacetonate oxygen atoms, while the apical position is taken by the pyridyl nitrogen atom of the oxime ligand. Adopting the trigonal bipyramidal description, the axial positions are occupied by $\mathrm{O}(2)$ and $\mathrm{O}(4)$ and the equatorial ones by $\mathrm{O}(3), \mathrm{O}(5)$, and $\mathrm{N}(1)$.

In the crystal lattice of $\mathbf{1} \cdot \mathrm{H}_{2} \mathrm{O}$, the molecules of $\mathbf{1}$ interact with the water lattice molecules through hydrogen bonds, forming a 2D network (Figure 2, Table 4).

Complex 2 is a new member of $\mathrm{Zn}(\mathrm{II})$ carboxylate complexes with a paddle wheel structure [17-20]. The $\mathrm{Zn}^{\mathrm{II}}$ ions are bridged by four $s y n, s y n-\eta^{1}: \eta^{1}: \mu \mathrm{MeCO}_{2}^{-}$ligands and each one has a perfect square pyramidal coordination geometry $(\tau=0.01)$, with the apex provided by the pyridyl nitrogen atom of a monodentate (3-py)CHNOH ligand. The $\mathrm{Zn} \cdots \mathrm{Zn}$ distance is $2.923(2) \AA$, while each $\mathrm{Zn}^{\mathrm{II}}$ ion lies $0.386 \AA$ out of its least-squares basal plane towards the pyridyl nitrogen atom. The mean $\mathrm{Zn}-\mathrm{O}$ (carboxylate) bond length is approximately $2.044 \AA$ which is typical and unremarkable [21]. There is a crystallographically imposed inversion center in the midpoint of the $\mathrm{Zn} \cdots$ Zn distance. 
TABle 3: Selected interatomic distances $(\AA)$ and angles $\left({ }^{\circ}\right)$ for complex $\mathbf{2}^{a}$.

\begin{tabular}{lccc}
\hline $\mathrm{Zn}-\mathrm{O}(2)$ & $2.088(3)$ & $\mathrm{Zn}-\mathrm{O}(4)$ & $2.016(3)$ \\
$\mathrm{Zn}-\mathrm{O}\left(3^{\prime}\right)$ & $2.055(3)$ & $\mathrm{Zn}-\mathrm{O}\left(5^{\prime}\right)$ & $2.016(3)$ \\
$\mathrm{Zn}-\mathrm{N}(1)$ & $2.049(4)$ & $\mathrm{Zn} \cdots \mathrm{Zn}^{\prime}$ & $2.923(2)$ \\
\hline $\mathrm{O}(4)-\mathrm{Zn}-\mathrm{O}\left(5^{\prime}\right)$ & $159.9(1)$ & $\mathrm{N}(1)-\mathrm{Zn}-\mathrm{O}\left(3^{\prime}\right)$ & $101.4(1)$ \\
$\mathrm{O}(4)-\mathrm{Zn}-\mathrm{N}(1)$ & $100.4(1)$ & $\mathrm{O}(4)-\mathrm{Zn}-\mathrm{O}(2)$ & $87.0(1)$ \\
$\mathrm{O}\left(5^{\prime}\right)-\mathrm{Zn}-\mathrm{N}(1)$ & $99.6(1)$ & $\mathrm{O}\left(5^{\prime}\right)-\mathrm{Zn}-\mathrm{O}(2)$ & $90.2(1)$ \\
$\mathrm{O}(4)-\mathrm{Zn}-\mathrm{O}\left(3^{\prime}\right)$ & $88.1(2)$ & $\mathrm{N}(1)-\mathrm{Zn}-\mathrm{O}(2)$ & $98.4(1)$ \\
$\mathrm{O}\left(5^{\prime}\right)-\mathrm{Zn}-\mathrm{O}\left(3^{\prime}\right)$ & $87.8(1)$ & $\mathrm{O}\left(3^{\prime}\right)-\mathrm{Zn}-\mathrm{O}(2)$ & $160.2(1)$ \\
\hline
\end{tabular}

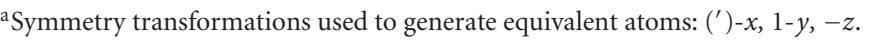

TABLE 4: Hydrogen bonding interactions in $\mathbf{1} \cdot \mathrm{H}_{2} \mathrm{O}$ and 2.

\begin{tabular}{lcccc}
\hline Interaction ${ }^{\mathrm{a}} \mathrm{D}-\mathrm{H} \cdots \mathrm{A}$ & $\mathrm{D} \cdots \mathrm{A}(\AA)$ & $\mathrm{H} \cdots \mathrm{A}(\AA)$ & $\mathrm{D}-\mathrm{H} \cdots \mathrm{A}\left({ }^{\circ}\right)$ & Symmetry operation of A \\
\hline $\mathbf{1} \cdot \mathrm{H}_{2} \mathrm{O}$ & & & & 115.0 \\
$\mathrm{O}(1 \mathrm{~W})-\mathrm{H}(1 \mathrm{WA}) \cdots \mathrm{O}(2)$ & 3.002 & 2.5600 & 168.0 & $1 / 2-x,-1 / 2+y, 1 / 2-z$ \\
$\mathrm{O}(1)-\mathrm{H}(1 \mathrm{O}) \cdots \mathrm{O}(1 \mathrm{~W})$ & 2.663 & 1.970 & 145.0 & $1-x,-y,-z$ \\
$\mathrm{O}(1 \mathrm{~W})-\mathrm{H}(1 \mathrm{WB}) \cdots \mathrm{N}(2)$ & 3.002 & 2.300 & & $x, y, z$ \\
$\mathbf{2}$ & & & 166.0 & $x, y,-1+z$ \\
$\mathrm{O}(1)-\mathrm{H}(1 \mathrm{O}) \cdots \mathrm{O} 2$ & 2.712 & 1.910 & & \\
\hline
\end{tabular}

${ }^{\mathrm{a}} \mathrm{A}=$ acceptor, $\mathrm{D}=$ donor.

In the crystal lattice of 2 , the dinuclear molecules interact through hydrogen bonds. Both oxime groups act as donors to carboxylate oxygen atoms, forming double, ladder-like chains along the $\mathrm{c}$ axis (Table 4, Figure 4).

3.3. IR Spectroscopy. The IR spectra of $\mathbf{1} \cdot \mathrm{H}_{2} \mathrm{O}$ and 2 exhibit weak bands at 3468 and $3454 \mathrm{~cm}^{-1}$, respectively, assignable to the $v(\mathrm{OH})$ vibration of the coordinated pyridyl oxime ligands [22]. The broadness and relatively low frequency of these bands are both indicative of hydrogen bonding. The medium intensity bands at 1636 and $1124 \mathrm{~cm}^{-1}$ in the spectrum of the free ligand (3-py)CHNOH are assigned to $v(\mathrm{C}=\mathrm{N})$ oxime and $v(\mathrm{~N}-\mathrm{O})$ oxime, respectively [23]. In the spectra of the complexes, these bands are observed at approximately the same wavenumbers, confirming the nonparticipation of the oxime group in coordination. The in-plane deformation band of the pyridyl ring of free (3py) $\mathrm{CHNOH}\left(638 \mathrm{~cm}^{-1}\right)$ shifts upwards $\left(654 \mathrm{~cm}^{-1}\right)$ in the spectra of $1 \cdot \mathrm{H}_{2} \mathrm{O}$ and 2 , confirming the crystallography established involvement of the ring- $\mathrm{N}$ atom in coordination [24].

The presence of chelating $\mathrm{acac}^{-}$ligands in complex $\mathbf{1} \cdot \mathrm{H}_{2} \mathrm{O}$ is reflected by the presence of two strong intensity bands at $1500-1600 \mathrm{~cm}^{-1}$. The higher frequency band $\left(1586 \mathrm{~cm}^{-1}\right)$ is attributed to $\nu(\mathrm{C} \stackrel{--}{-})$ coupled with $\nu(\mathrm{C} \stackrel{--}{-})$, while the lower frequency band $\left(1552 \mathrm{~cm}^{-1}\right)$ is attributed to $\nu(\mathrm{C} \stackrel{--}{-} \mathrm{O})$ coupled with $\nu(\mathrm{C} \stackrel{--}{-})[25]$.

The strong intensity bands at 1522 and $1400 \mathrm{~cm}^{-1}$ in the spectrum of 2 are assigned to the $v_{\mathrm{as}}\left(\mathrm{CO}_{2}\right)$ and $v_{s}\left(\mathrm{CO}_{2}\right)$ modes of the acetate ligands, respectively [26]; the former may also involve a pyridyl stretching character. The

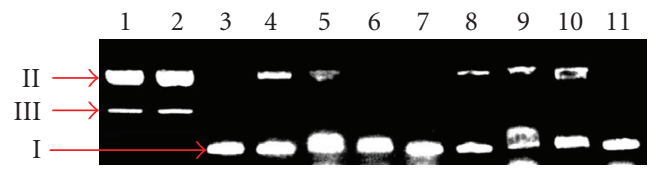

Figure 5: Agarose gel electrophoresis pattern of pDNA in the presence of the synthesized complexes and (3-py)CHNOH in various concentrations. Lane $1, \mathrm{DNA}+\mathbf{1} \cdot \mathrm{H}_{2} \mathrm{O}(5 \mathrm{mM})$; lane 2 , $\mathrm{DNA}+2$ (5 mM); lane 3, DNA+ (3-py)CHNOH (5 mM); lane 4, $\mathrm{DNA}+\mathbf{1} \cdot \mathrm{H}_{2} \mathrm{O}(2.5 \mathrm{mM})$; lane 5 , DNA $+2(2.5 \mathrm{mM})$; lane 6, DNA + (3-py)CHNOH (2.5 mM); lane 7, DNA + 1· $\mathrm{H}_{2} \mathrm{O}(1 \mathrm{mM})$; lane 8, DNA + $2(1 \mathrm{mM})$; lane 9, DNA + $1 \cdot \mathrm{H}_{2} \mathrm{O}(0.1 \mathrm{mM})$; lane 10, DNA + $2(0.1 \mathrm{mM})$; lane 11 , DNA control.

difference $\Delta$, where $\Delta=v_{\text {as }}\left(\mathrm{CO}_{2}\right)-v_{\mathrm{s}}\left(\mathrm{CO}_{2}\right)$, is $122 \mathrm{~cm}^{-1}$, less than that for $\mathrm{NaO}_{2} \mathrm{CMe}\left(164 \mathrm{~cm}^{-1}\right)$, as expected for bidentate bridging ligation [26].

3.4. Effect on pDNA. DNA mobility shift assays were carried out to investigate the ability of complexes $\mathbf{1} \cdot \mathrm{H}_{2} \mathrm{O}$ and $\mathbf{2}$, as well as that of the (3-py)CHNOH free ligand to interact with plasmid DNA. The initial amount of pDNA was incubated with increasing concentrations of the tested compounds. When circular pDNA is subjected to electrophoresis, relatively fast migration will be observed for the supercoiled form (form I). If scission occurs on one strand (nicking), the supercoils will relax to generate a slower-moving open relaxed form (form II) [27]. If both strands are cleaved, a linear form (form III) will be generated and migrate between forms I and II [28].

Figure 5 shows the gel electrophoretic separations of pDNA after incubation with $\mathbf{1} \cdot \mathrm{H}_{2} \mathrm{O}, 2$ and (3-py) CHNOH 
at various concentrations. Both complexes can break the double strand of pDNA and convert it to the relaxed form (II) and in a less extent to its linear form (III), at a concentration of $5 \mathrm{mM}$ (Figure 5, lanes 1 and 2). At lower concentrations, the complexes display a minor effect on the integrity and electrophoretic mobility of pDNA, whereas the latter remains mostly in the supercoiled form (I). The (3py) $\mathrm{CHNOH}$ ligand (Figure 5, lanes 3 and 6) does not display any interaction.

\section{Conclusions}

Two new complexes of $\mathrm{Zn}^{\mathrm{II}}$, with 3-pyridine aldoxime as ligand, have been synthesized and characterized by singlecrystal X-ray crystallography, elemental analyses, and IR spectroscopy. In both structures, (3-py) $\mathrm{CHNOH}$ acts as a monodentate ligand via the pyridyl nitrogen, while the oxime group does not participate in coordination. This coordination mode is the only one observed in complexes of (3-py) $\mathrm{CHNOH}$ with any metal up to date. Complexes $\mathbf{1} \cdot \mathrm{H}_{2} \mathrm{O}$ and $\mathbf{2}$ are the second and the third structurally characterized $\mathrm{Zn}$ (II) complexes of (3-py) CHNOH.

The two complexes affect both the integrity and electrophoretic mobility of pDNA. At the highest tested concentration, $\mathbf{1} \cdot \mathrm{H}_{2} \mathrm{O}$ and $\mathbf{2}$ are able to totally convert the supercoiled form of pDNA to the relaxed form and in less extent to its linear form. Other types of DNA-binding experiments are currently in progress in order to determine the way of interaction with pDNA. In the future, synthetic efforts with different types of anionic ligands (e.g., $\mathrm{NO}_{3}^{-}$, $\mathrm{SO}_{4}^{2-}$ ) can lead to a variety of (3-py) $\mathrm{CHNOH}$ complexes with potentially interesting DNA-binding properties.

\section{Acknowledgments}

E.Manessi-Zoupa and K.F.Konidaris thank the Research Committee of the University of Patras for funding this work (C. Carathéodory Grant 2008, no. C.584). This contribution is devoted to Professor Nick Hadjiliadis on the occasion of his retirement and for his great contributions to Bioinorganic Chemistry.

\section{References}

[1] C. Tan, J. Liu, L. Chen, S. Shi, and L. Ji, "Synthesis, structural characteristics, DNA binding properties and cytotoxicity studies of a series of $\mathrm{Ru}(\mathrm{III})$ complexes," Journal of Inorganic Biochemistry, vol. 102, no. 8, pp. 1644-1653, 2008.

[2] Y.-M. Song, Q. Wu, P.-J. Yang, N.-N. Luan, L.-F. Wang, and Y.M. Liu, "DNA Binding and cleavage activity of Ni(II) complex with all-trans retinoic acid," Journal of Inorganic Biochemistry, vol. 100, no. 10, pp. 1685-1691, 2006.

[3] G. Zuber, J. C. Quada Jr., and S. M. Hecht, "Sequence selective cleavage of a DNA octanucleotide by chlorinated bithiazoles and bleomycins," Journal of the American Chemical Society, vol. 120, no. 36, pp. 9368-9369, 1998.

[4] F. R. Keene, J. A. Smith, and J. G. Collins, "Metal complexes as structure-selective binding agents for nucleic acids," Coordination Chemistry Reviews, vol. 253, no. 15-16, pp. 2021-2035, 2009.
[5] L. J. K. Boerner and J. M. Zaleski, "Metal complex-DNA interactions: from transcription inhibition to photoactivated cleavage," Current Opinion in Chemical Biology, vol. 9, no. 2, pp. 135-144, 2005.

[6] B. Lippert, "Multiplicity of metal ion binding patterns to nucleobases," Coordination Chemistry Reviews, vol. 200-202, pp. 487-516, 2000.

[7] E. L. Hegg and J. N. Burstyn, "Toward the development of metal-based synthetic nucleases and peptidases: a rationale and progress report in applying the principles of coordination chemistry," Coordination Chemistry Reviews, vol. 173, no. 1, pp. 133-165, 1998.

[8] X. Sheng, X. Guo, X.-M. Lu et al., "DNA binding, cleavage, and cytotoxic activity of the preorganized dinuclear zinc(II) complex of triazacyclononane derivatives," Bioconjugate Chemistry, vol. 19, no. 2, pp. 490-498, 2008.

[9] H. Zhang, C.-S. Liu, X.-H. Bu, and M. Yang, "Synthesis, crystal structure, cytotoxic activity and DNA-binding properties of the copper (II) and zinc (II) complexes with 1-[3-(2pyridyl)pyrazol-1-ylmethyl] naphthalene," Journal of Inorganic Biochemistry, vol. 99, no. 5, pp. 1119-1125, 2005.

[10] H. Xu, K.-C. Zheng, Y. Chen et al., "Effects of ligand planarity on the interaction of polypyridyl $\mathrm{Ru}(\mathrm{II})$ complexes with DNA," Dalton Transactions, pp. 2260-2268, 2003.

[11] C. J. Milios, T. C. Stamatatos, and S. P. Perlepes, "The coordination chemistry of pyridyl oximes," Polyhedron, vol. 25, no. 1, pp. 134-194, 2006.

[12] K. F. Konidaris, E. Katsoulakou, M. Kaplanis et al., "A tetrahedron in a cube: a dodecanuclear $\mathrm{Zn}^{I I}$ benzoate cluster from the use of 2-pyridinealdoxime," Dalton Transactions, vol. 39, no. 19, pp. 4492-4494, 2010.

[13] K. F. Konidaris, M. Kaplanis, C. P. Raptopoulou, S. P. Perlepes, E. Manessi-Zoupa, and E. Katsoulakou, "Dinuclear versus trinuclear complex formation in zinc(II) benzoate/pyridyl oxime chemistry depending on the position of the oxime group," Polyhedron, vol. 28, no. 15, pp. 3243-3250, 2009.

[14] G. M. Sheldrick, SHELXS-97, Structure Solving Program, University of Göttingen, Göttingen, Germany, 1997.

[15] G. M. Sheldrick, SHELXL-97, Crystal Structure Refinement Program, University of Göttingen, Göttingen, Germany, 1997.

[16] A. W. Addison, T. N. Rao, J. Reedijk, J. van Rijn, and G. C. Verschoor, "Synthesis, structure, and spectroscopic properties of copper(II) compounds containing nitrogen-sulphur donor ligands; the crystal and molecular structure of aqua[1,7-bis( $N$-methylbenzimidazol-2' -yl)-2,6dithiaheptane]copper(II) perchlorate," Journal of the Chemical Society, Dalton Transactions, no. 7, pp. 1349-1356, 1984.

[17] H. Kwak, S. H. Lee, S. H. Kim et al., "Substituent effects of pyrazine on construction of crystal structures of $\mathrm{Zn}$ (II)benzoate complexes and their catalytic activities (dinuclear, trinuclear, and pentanuclear to 1-D and 2-D)," Polyhedron, vol. 27, no. 17, pp. 3484-3492, 2008.

[18] A. Karmakar, R. J. Sarma, and J. B. Baruah, "Self-assembly of neutral dinuclear and trinuclear zinc-benzoate complexes," Inorganic Chemistry Communications, vol. 9, no. 12, pp. 11691172, 2006.

[19] V. Zeleňák, M. Sabo, W. Massa, and J. Černák, “Tetra- $\mu$ benzoato- $\kappa^{8} O: O^{\prime}$-bis $(\{1-[(3,4-$ dimethoxyphenyl $)$ methyl $]-$ 6, 7-dimethoxyisoquinoline- $\kappa N\}$ zinc(II)): the first crystal structure with papaverine as a ligand," Acta Crystallographica Section C, vol. 60, no. 2, pp. m85-m87, 2004.

[20] H. Necefoglu, W. Clegg, and A. J. Scott, "Tetrakis $(\mu-$ benzoato)bis[(N,N-diethylnicotinamide)zinc(II)]," Acta Crystallographica E, vol. 58, pp. m121-m122, 2002. 
[21] Q. Zhou, T. W. Hambley, B. J. Kennedy et al., "Syntheses and characterization of anti-inflammatory dinuclear and mono-nuclear zinc indomethacin complexes. Crystal structures of $\left.\left[\mathrm{Zn}_{2} \text { (indomethacin }\right)_{4}(\mathrm{~L})_{2}\right] \quad(\mathrm{L}=N, N-$ dimethylacetamide, pyridine, 1-methyl-2-pyrrolidinone) and [Zn(indomethacin $\left.)_{2}\left(\mathrm{~L}_{1}\right)_{2}\right]\left(\mathrm{L}_{1}=\right.$ ethanol, methanol)," Inorganic Chemistry, vol. 39, no. 17, pp. 3742-3748, 2000.

[22] K. W. Nordquest, D. W. Phelps, W. F. Little, and D. J. Hodgson, "Metal-metal interactions in linear chains. The structure and characterization of bis(pyridine-2carboxaldoximinato)platinum(II)dihydrate," Journal of the American Chemical Society, vol. 98, no. 5, pp. 1104-1107, 1976.

[23] P. Chaudhuri, M. Winter, U. Flörke, and H.-J. Haupt, "An effectively diamagnetic oximato-bridged asymmetric dinuclear copper(II) complex with a $\mathrm{Cu}(\mathrm{II})$-I bond," Inorganica Chimica Acta, vol. 232, no. 1-2, pp. 125-130, 1995.

[24] A. B. P. Lever and E. Mantovani, "The far-infrared and electronic spectra of some bis-ethylenediamine and related complexes of copper(II) and the relevance of these data to tetragonal distortion and bond strengths," Inorganic Chemistry, vol. 10, no. 4, pp. 817-826, 1971.

[25] K. Nakamoto, Infrared and Raman Spectra of Inorganic and Coordination Compounds, John Wiley \& Sons, New York, NY, USA, 4th edition, 1986.

[26] G. B. Deacon and R. J. Phillips, "Relationships between the carbon-oxygen stretching frequencies of carboxylato complexes and the type of carboxylate coordination," Coordination Chemistry Reviews, vol. 33, pp. 227-250, 1980.

[27] J. K. Barton and A. L. Raphael, "Photoactivated stereospecific cleavage of double-helical DNA by cobalt(III) complexes," Journal of the American Chemical Society, vol. 106, no. 8, pp. 2466-2468, 1984.

[28] X.-Q. He, Q.-Y. Lin, R.-D. Hu, and X.-H. Lu, "Synthesis, characterization and DNA-binding studies on $\mathrm{La}(\mathrm{III})$ and $\mathrm{Ce}(\mathrm{III})$ complexes containing ligand of $\mathrm{N}$-phenyl-2pyridinecarboxamide," Spectrochimica Acta A, vol. 68, no. 1, pp. 184-190, 2007. 


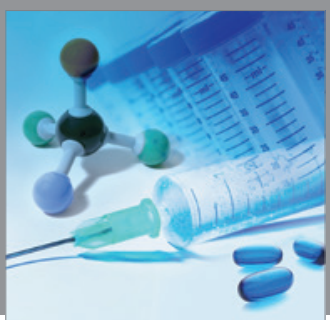

International Journal of

Medicinal Chemistry

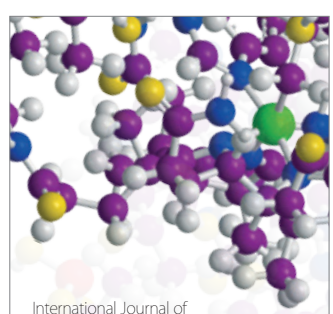

Carbohydrate Chemistry

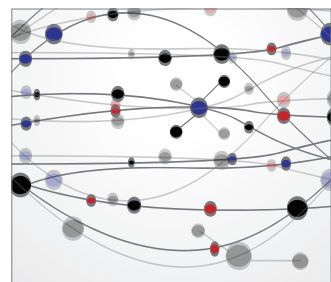

The Scientific World Journal
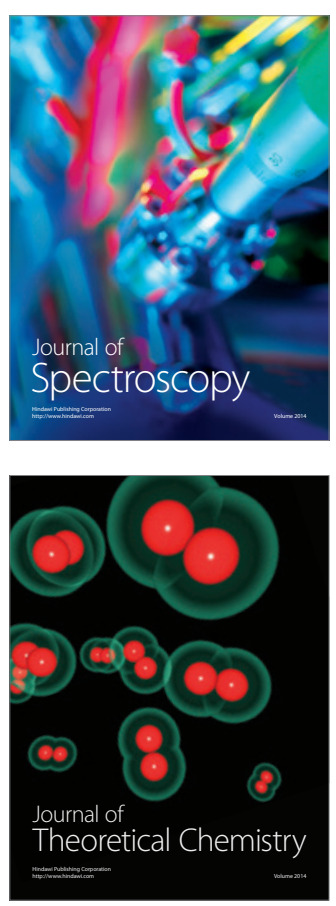
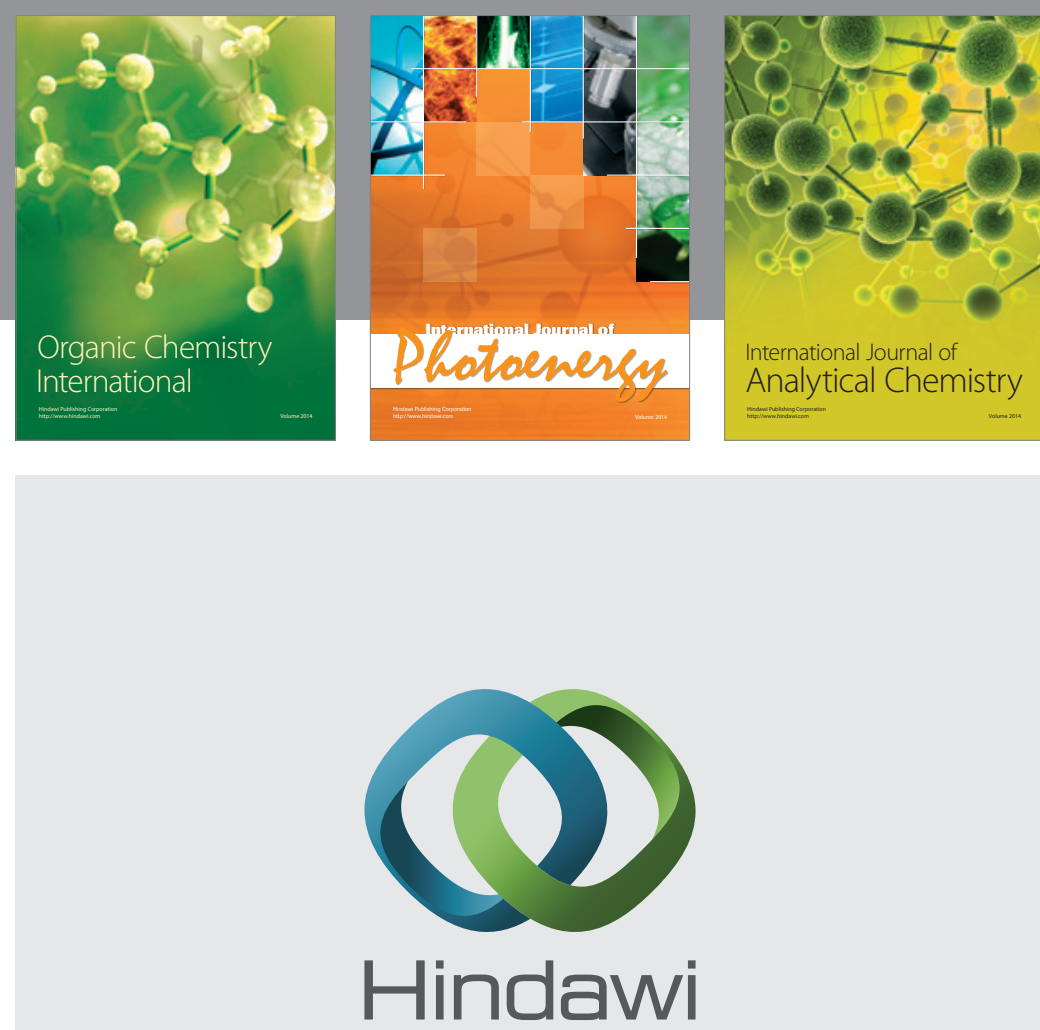

Submit your manuscripts at

http://www.hindawi.com
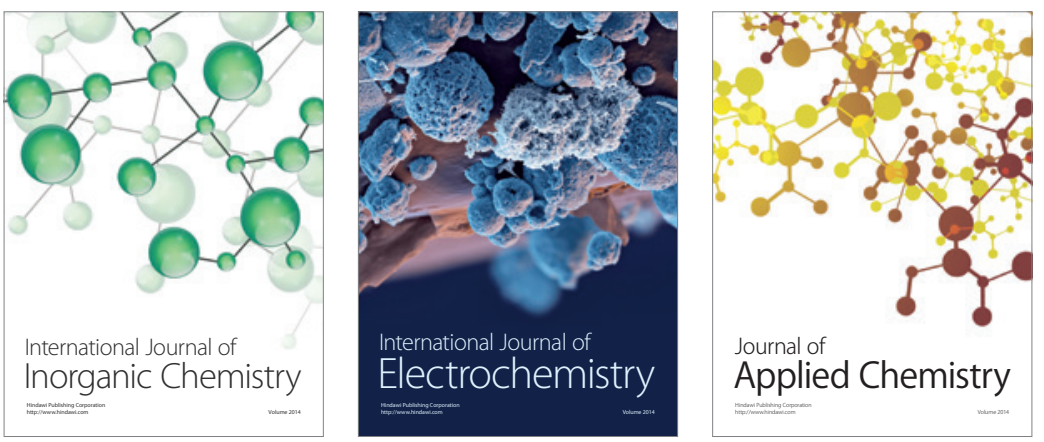

Journal of

Applied Chemistry
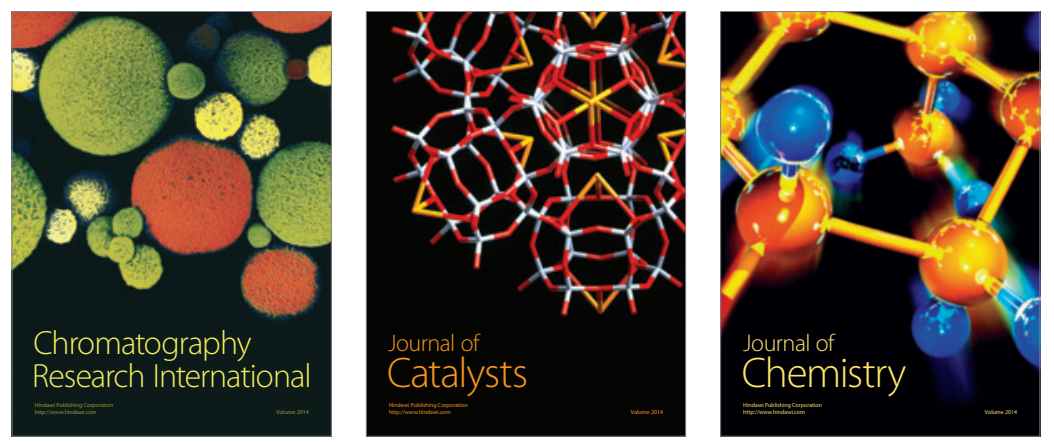
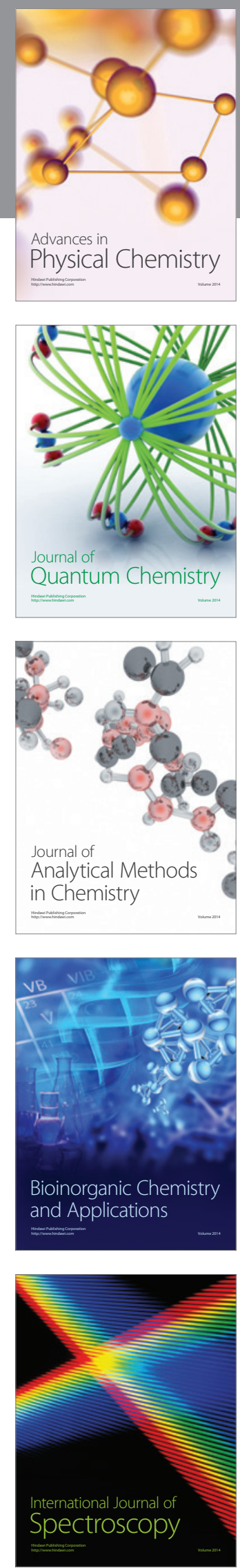